\title{
Applying a floristic originality index in tropical forests of south Sinaloa, Mexico
}

\section{Aplicando um índice de originalidade florística em florestas tropicais do sul de Sinaloa, México}

\author{
Francisco Amador-Cruz ${ }^{1}$, George Bruno Bordenave ${ }^{2,3}$, Daniel Benítez-Pardo ${ }^{4}$
}

1 FAC Consultoría Ambiental, 129 Cerro Largo, 82110, Mazatlán, Mexico

2 BGB Consultance - Tropical Botany, 9 Route des Grandes Roches, 29910 Trégunc, France

3 Université de Bretagne Occidentale (UBO), Département de Biologie, Brest, France

4 Autonomous University of Sinaloa, Sea Sciences Faculty, Laboratory of Aquatic Botanic. Paseo Claussen S/N, Col. Los pinos, C.P. 82000, Postal mail 610. Mazatlán, Sinaloa, Mexico

Corresponding author: Francisco Amador-Cruz (famadorc.facimar@uas.edu.mx)

Academic editor:A.M. Leal-Zanchet | Received 18March 2019 | Accepted 25November 2019 | Published 18 December 2019

Citation: Amador-Cruz F, Bordenave GB, Benítez-Pardo D (2019) Applying a floristic originality index in tropical forests of south Sinaloa, Mexico. Neotropical Biology and Conservation 14(4): 539-557. https://doi.org/10.3897/ neotropical.14.e49166

\begin{abstract}
Sinaloa is among the states of Mexico harboring the highest deforestation rates. Reforestation programs have been put up in south Sinaloa with species chosen for their high seedling rates, structural importance or strong restoration value. However, species criteria such as level of endemism as well as rarity appear to be underestimated. Eight sampling sites were randomly selected and a botanical survey was carried out at least every month from 2015 to 2017. In order to rank species over conservation stakes, a Floristic Originality Index method was elaborated using species level of endemism, rarity and conservation status. The floristic inventory enabled the identification of a set of 250 species with the Fabaceae being the most represented family with 51 species. Using the Floristic Originality Index, a subset of 51 species was selected as priority for conservation along with 23 other species all displaying characteristics of "framework" species. Features of reproduction and types of ideal soil conditions for reforestation are presented for each species. The method developed to determine floristic originality has proven a set of most vulnerable and rare species to select "priority" and "framework" tree species able to restore forests structure and biodiversity as well as ecosystem functions. This evaluation is made from a conservation biology point of view and appears to be well adapted for studies at a local scale.
\end{abstract}




\section{Resumo}

Sinaloa é um dos estados com o maior índice de desmatamento no México. Programas de reflorestamento têm sido implantados na porção sul, utilizando espécies com taxas de plântulas elevadas, importância estrutural ou alto valor de restauração. No entanto, critérios como níveis de endemismo e raridade das espécies parecem estar subestimados. Neste trabalho, realizou-se um inventário florístico, ao menos a cada mês, durante três anos (2015-17) em oito locais de amostragem selecionados aleatoriamente. Elaborou-se um método de Índice de Originalidade Florística, utilizando nível de endemismo de espécies, raridade e estado de conservação para classificar espécies raras. O inventário florístico resultou em um conjunto de 250 espécies identificadas, sendo Fabaceae ( $\mathrm{S}=51$ ) a família com o maior número de espécies. Usando o Índice de Originalidade Florística, um subconjunto de 51 espécies foi selecionado como prioritário para a conservação, somando-se a 23 outras espécies que exibem todas as características de espécies "framework". Características de reprodução e os tipos de condições ideais de solo para o reflorestamento de cada espécie são apresentadas. O método desenvolvido para determinar a originalidade provou um conjunto de espécies mais vulneráveis e raras para selecionar espécies de árvores "prioritárias" e "estruturais" capazes de restaurar a estrutura e a biodiversidade das florestas, bem como as funções do ecossistema. Esta avaliação é feita do ponto de vista da biologia da conservação e está bem adaptada para estudos em nível local.

\section{Keywords}

conservation priorities, endemism, flora composition, framework species, rarity, tropical forest, wild vegetation

\section{Palavras-chave}

composição florística, endemismo, espécie de estrutura, floresta tropical, prioridades de conservação, raridade, vegetação nativa

\section{Introduction}

The global concern about the reduction of tropical forests due to human activities is increasing. According to recent studies (Wright and Muller-Landau 2006; Elliott et al. 2013; Chazdon 2014) some 35 to $50 \%$ of the surface areas of these plant communities has been destroyed worldwide. The main consequences are usually: soil Carbon and Nitrogen stock loss (Assefa et al. 2017), effects on trophic interactions, hydrological alterations (Runyan and D'Odorico 2016), increasing of temperatures and diseases (Kweka et al. 2016), as well as biodiversity loss (Geist and Lambin 2002; Addo-Fordjour et al. 2009; Mwakalukwa et al. 2014; Egbinola 2015). The latest is associated with patterns of human activity (Sala et al. 2000) because the climax ecosystems are replaced by secondary vegetation, with an obvious weakening of the vegetation structure and floristic composition (Corlett 1994).

Such phenomena can be illustrated in the example of the state of Sinaloa, Mexico, where 4\% of temperate and tropical forest has vanished between 1993 and 2011 with an average annual rate of deforestation of $0.41 \%$ (Monjardín-Armenta et al. 2017). This places Sinaloa among the 15 states with the highest rate of deforestation in Mexico (Aguilar-Sierra et al. 2000). Agriculture and livestock farming are the 
main identified factors for this loss (Monjardín-Armenta et al. 2017). In response to this concern, reforestation programs have been put up by institutions such as CONAFOR (Comisión Nacional Forestal), PRONATURA A. C., CONSELVA A. C., FONATUR (Fondo Nacional de Fomento al Turismo), among others. In general, the criteria used to select reforestation species are high seedling rates, structural importance or high restoration value. However, other important criteria such as species levels of endemism as well as rarity appear to be underestimated (Forest Restoration Research Unit 2000).

With an overall floristic richness reaching 3737 species (Villaseñor-Ríos 2016; Amador-Cruz et al. 2017), the state of Sinaloa harbors a great variety of vegetation types. Four major vegetation types can be distinguished in Sinaloa tropical forests: (i) dry forest, (ii) semideciduous forest, (iii) cloud forest, and (iv) mangroves (Whitmore 1998; Vega-Aviña et al. 2000; Elliott et al. 2013; INEGI 2013; CONAFOR 2014). Although most of these ecosystems are located in northern Sinaloa, the southern part of the state harbors the largest area of semideciduous forest, considered as more diverse (CONAFOR 2014); in addition, the mangroves in the south are the most preserved of the entire Pacific coast of Mexico (CONANP 2008). Both plants communities, as well as dry forest, are found in the Region of Palmito de Verde (RPV), which includes the municipalities of Escuinapa and Rosario.

The aim of this study is to determine a set of most vulnerable and rare species through a modified Floristic Originality Index (Rabinowitz 1981; Rabinowitz et al. 1986) in order to select "framework" tree species able to restore forests' structure and biodiversity as well as ecosystem functions (Forest Restoration Research Unit 2000). The modification consists of implementing the "Threat" criteria that is now taken into account in public policies of vulnerable species protection. This attribute can be considered as essential for conservation since the selection of a species within this list leads to a meticulous study of the population's distribution and inter and intraspecific relationships (IUCN 2001; SEMARNAT 2010; Sánchez-Salas et al. 2013).

\section{Methods}

\section{Study area}

In the southern part of the state of Sinaloa (Fig. 1), the Region of Palmito de Verde (municipalities of Escuinapa and Rosario) is part of a RAMSAR site (Marismas Nacionales, number 732). It has a tropical climate with significant summer rainfall and can be classified as of Awo (w)(e) type (García 2004; Servicio Meteorológico Nacional 2010). Furthermore, four main soil types can be distinguished, from most to least common (i) hiposalic gleyic Arenosol /Regosol, (ii) hypersodic gleyic Solonchak, (iii) eutric epileptic Cambisol, and (iv) hiposodic hiposalic Phaeozem, the first mostly in semideciduous forests, the second in mangroves, the third in dry forest and the last in riparian vegetation (INEGI 2014). 


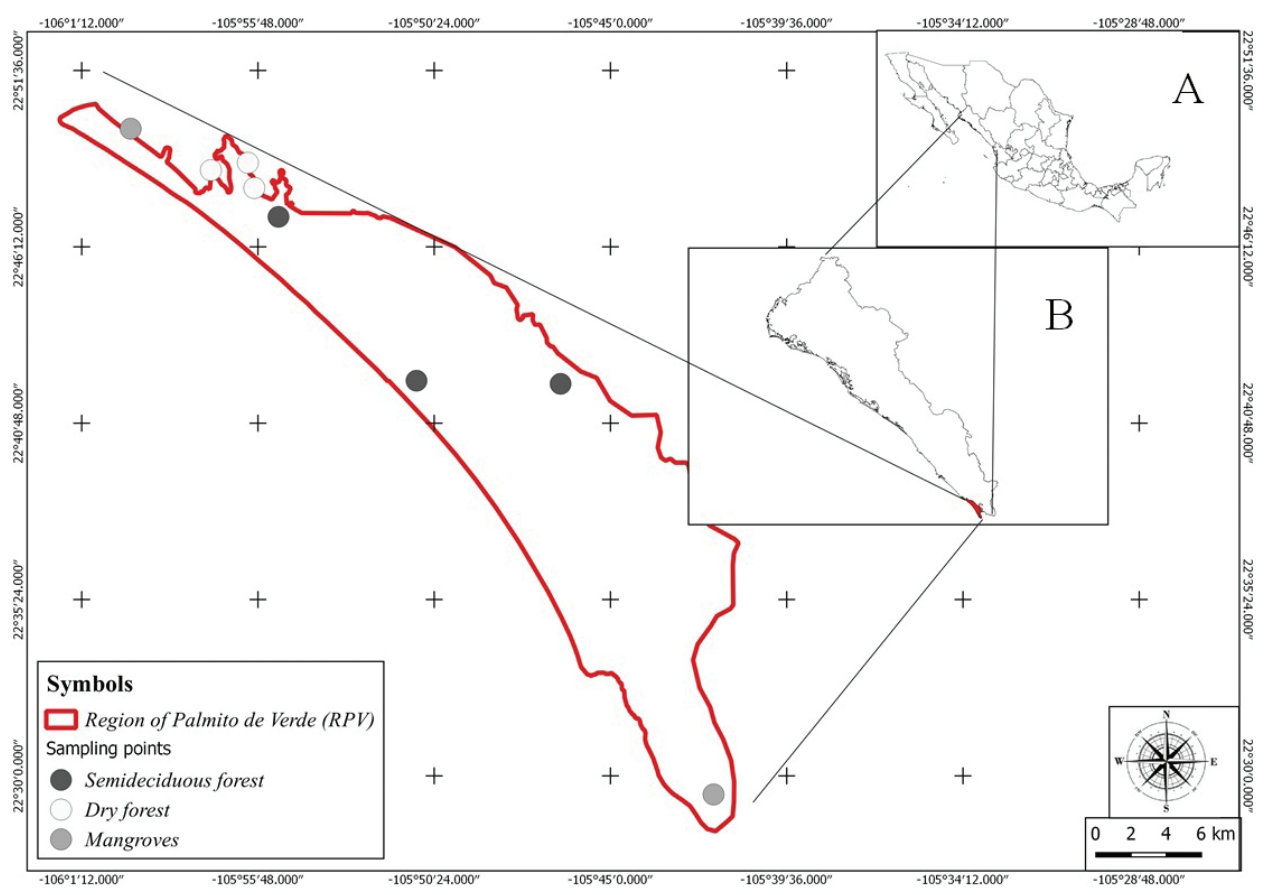

Figure 1. Map of the study area (Region of Palmito de Verde), sampling sites by vegetation type. A Mexico; B state of Sinaloa. Background map INEGI $(1995,2016)$.

\section{Sampling points}

Satellite images were used to identify the area best representing primary mangroves and dry or semideciduous forest vegetation. Through use of the 'random points inside polygons' tool, in QGIS2.18.7 Las Palmas de G.C., eight sampling sites were randomly selected within the area covered by vegetation. With the intention to produce a floristic inventory, in each sampling point a plot of $400 \mathrm{~m}^{2}$, with three repetitions, was established (Phillips et al. 2003). A botanical survey was conducted every month, alternating the collecting site during 27 months (2015-2017), in order to cover the full phenology and gather a collection of fertile specimens for the plant species on site (Shaheen et al. 2014) (Figs 1, 2). Over 600 herbarium specimens were collected, mostly flowering and fruiting, but some sterile specimens were also collected for more common and well-known species (Gonçalves and Goyder 2016). The geographical coordinates, collector's name, date, habitat, phenology, and other features are provided on voucher labels (Shaheen et al. 2014; Luize et al. 2015). Botanical specimens have been deposited at herbarium Jesús González Ortega of the Autonomous University of Sinaloa (acronym: UAS) and Herbarium of Center for Research in Food and Development (acronym: HCIAD), both located in the state of Sinaloa, Mexico. The nomenclature used is that proposed by Tropicos (2019). 

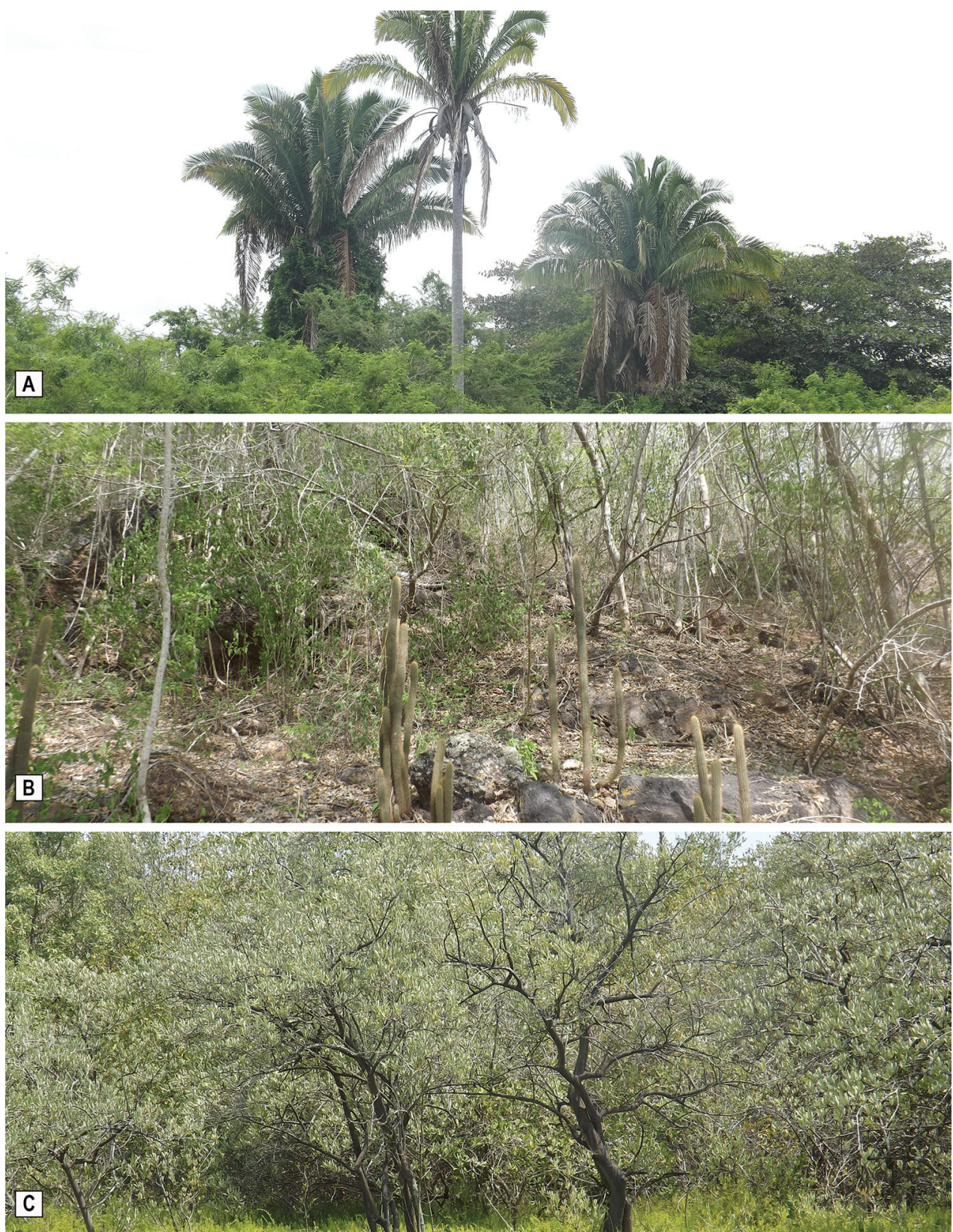

Figure 2. Types of tropical vegetation in the Region of Palmito de Verde, state of Sinaloa, Mexico: A semideciduous forest, $\mathbf{B}$ dry forest, $\mathbf{C}$ mangroves. 


\section{Floristic Originality Index (FOI)}

The method developed by Rabinowitz to determine levels of originality is very useful to evaluate the rarity of the species at the local level, under the premise that if the causes of the rarity of some species are diverse, the ecological effects could be equally diverse (Kruckeberg and Rabinowitz 1985; Broennimann et al. 2005). However, the ranking of most species through IUCN categories is yet to be achieved in some regions. Hence, the need for operational tools to guide public policies over biodiversity protection and restoration requires the implementation of the "Threat" criteria to assign a practical conservation value that can be used by government institutions (SEMARNAT 2010), international bodies (IUCN 2016; CITES 2017) and NGO's. The Floristic Originality Index method developed herein modifies Rabinowitz's rare species ranking system (Rabinowitz 1981; Rabinowitz et al. 1986): it takes into account the species threat level at the region scale, in addition to distribution range, endemism, and rarity.

To avoid a double assignment, species were sorted as Threatened or Not Threatened. The first case included all species that have some category of vulnerability according to the NOM-059 (SEMARNAT 2010), in categories equivalent to those of IUCN (2001) or incorporated in some appendix of CITES (2017) (Table 1).

To assign a value to the "Threat" criteria, three possible scales were investigated, of which two were linear models and the other was over a base 2 exponential (Table 2), considering that rarity is likely not linear since the causes of species dwindling are multi-factor (Rabinowitz 1981). Furthermore, a minimum value of 1 was assigned to every species, in order to acknowledge its intrinsic value and to include "ordinary" biodiversity in conservation topic (Gaston and Fuller 2007; Devineau et al. 2009; Godet 2010; Brédif and Simon 2014; Couvet and Ducarme 2014; Couvet and Vandevelde 2014). Subsequent values were plotted using the R 3.0.0. software (R Core Team 2017), to compare alternative progression trends (Fig. 3).

At the beginning, the " $\mathrm{x}$ " value in the three functions was similar, and the threat value remains nearly identical at $\mathrm{x}=3$. However, the exponential function model fits the expected progression better since the threat value rises slightly with $\mathrm{x}=4$ and more obviously with $x>5$. Hence, the exponential model was eventually chosen as it provides a relevant starting point as to when to consider a species as a conservation priority.

The considered criteria were limited to the following characteristics (Rabinowitz 1981; Kruckeberg and Rabinowitz 1985; Broennimann et al. 2005):

Geographic range - Large: the distribution of the species was large in the country, or was cosmopolite, Restricted range endemic: the species was distributed only on the Pacific coast of Mexico, or was only present in the states surrounding Sinaloa.

Habitat specificity - Wide: the species had the ability to develop in various types of vegetation, Narrow: the species grew in only one, or two types of vegetation (eco-endemic). 
Table 1. Categories included in "Threat" criteria. Categories in the same row are equivalents.

\begin{tabular}{lcc}
\hline NOM-059 (SEMARNAT 2010) & Category of The Red List (IUCN, 2001) & CITES (2017) \\
\hline Special Protection (Pr) & Near Threatened (NT) & - \\
Threatened (A) & Vulnerable (VU) & - \\
& Endangered (EN) & - \\
Endangered (P) & Critically Endangered (CR) & Appendices I \\
& & Appendices II \\
\hline
\end{tabular}

Table 2. Species rarity values including a "Threat" criteria, assigned with 3 different scale models.

\begin{tabular}{|c|c|c|c|c|c|c|}
\hline & & \multirow{2}{*}{$\begin{array}{l}\text { Geographic range } \\
\text { Habitat specificity }\end{array}$} & \multicolumn{2}{|c|}{ Large } & \multicolumn{2}{|c|}{$\begin{array}{c}\text { Small (restricted range } \\
\text { endemic) }\end{array}$} \\
\hline & & & Wide & Narrow & Wide & Narrow \\
\hline \multirow{8}{*}{ 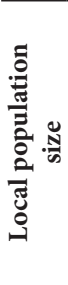 } & \multirow[t]{4}{*}{ Large, dominant by places } & \multirow{4}{*}{$\begin{array}{c}\text { Not Threatened } \\
\text { Threatened }\end{array}$} & 1 & 2 & 3 & 4 \\
\hline & & & 3 & 4 & 5 & 6 \\
\hline & & & 2 & 4 & 6 & 8 \\
\hline & & & 2 & 4 & 8 & 16 \\
\hline & \multirow{4}{*}{ Small, non-dominant } & \multirow{4}{*}{$\begin{array}{c}\text { Not Threatened } \\
\text { Threatened }\end{array}$} & 5 & 6 & 7 & 8 \\
\hline & & & 7 & 8 & 9 & 10 \\
\hline & & & 10 & 12 & 14 & 16 \\
\hline & & & 32 & 64 & 128 & 256 \\
\hline
\end{tabular}

Dark grey linear model $[\mathrm{x}+2]$; mid grey linear model $\left[\mathrm{x}^{\star} 2\right]$; light grey.one exponential $[2 \mathrm{x}]$

\section{Value of the 'Threat' criteria}

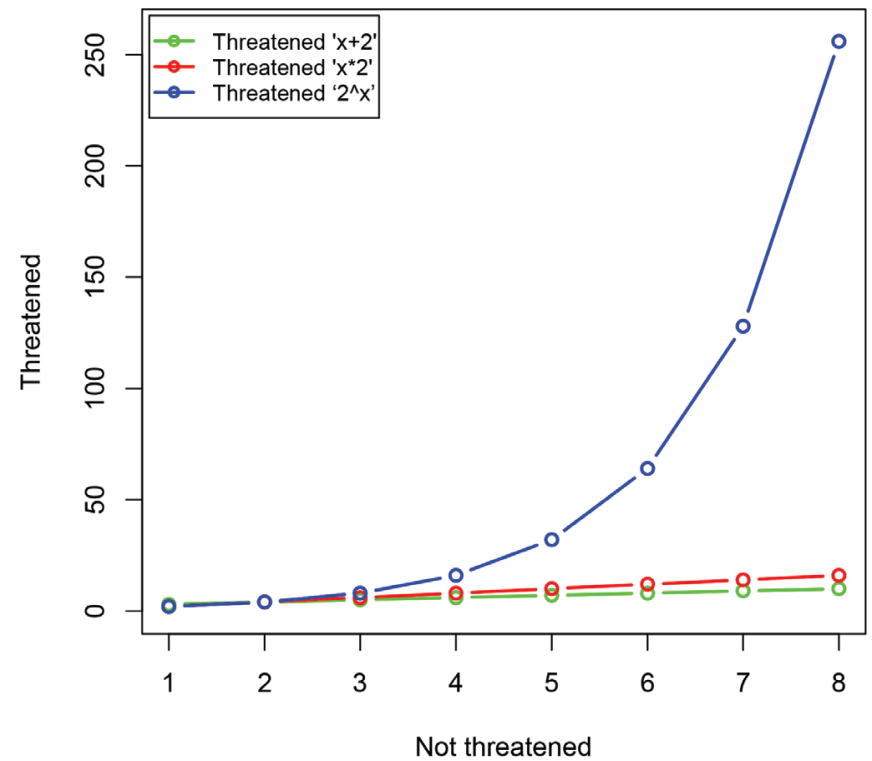

Figure 3. Alternative progressions with various scale models using statistical software R (R Core Team, 2017). 
Local population size - Large, dominant by place: either by natural means, or as invasive, the population of these species tended to dominate the plant community where it grew, Small, non-dominant: population's abundance was always limited by the species biogeographics, or natural history characteristics.

Threat - Not threatened: no regulation protection of the species populations (or not evaluated), Threatened: at least one regulation (SEMARNAT 2010; IUCN 2016; CITES 2017) acknowledged the species population was under a risk status.

\section{"Framework" species}

The "framework" species are characterized by fast growth, developing high population density, rapid adaptation to degraded sites, contributing to weed control and/or providing resources for wildlife (e.g. edible fruit or seed, nectar, roosting, or nesting sites, etc.) (Kerby et al. 2000). Such species also help prevent fire, improve the vegetation structure, attract seed-dispersing animals and accelerate the ecosystem function and recovery of biodiversity (Forest Restoration Research Unit 2000; Blakesley et al. 2002; Goosem and Tucker 2012; Betts 2013; Elliott et al. 2013). This way, the Region of Palmito de Verde (RPV) species complying with at least two of these characteristics have been established as "framework" species.

A table with biological and ecological features of each "priority" and "framework" species is presented (Suppl. material 1: Table S1), providing reproduction features, ideal soil types and reforestation ability. It was built using the Seed Information Database (RBG Kew 2008) and the studies about germination, reforestation, and restoration developed at the south of Sinaloa (Benítez-Pardo et al. 2016; Benítez-Pardo et al. 2017; Benítez-Pardo et al. 2018).

\section{Results}

The floristic inventory carried out in the study area found a set of 250 identified species belonging to 200 genera and 74 families. Fabaceae was the most represented with 51 species (21\%), followed by Euphorbiaceae (6\%) and Malvaceae (5.6\%) (Suppl. material 1: Table S2).

A subset of 51 species identified as vulnerable was selected using the Floristic Originality Index (FOI values $\geq 5$ ) and hence were prioritized as concerns for conservation (Table 3 ).

Additionally, 23 species gathering the most characteristics of "framework" species were selected. Thus, we propose a set of 74 priority species, 51 of concern for conservation and 23 meeting the most characteristics as "framework" species (Table 4, Fig. 4). The most favorable reproduction characteristics and conditions for these 51 'priority' and 23 'framework' species are presented in Suppl. material 1: Table S1. 
Table 3. Conservation priorities species ranked by Floristic Originality Index (FOI) value.

\begin{tabular}{|c|c|c|}
\hline $\mathrm{Sp} \#$ & $\begin{array}{c}\text { Taxa } \\
\end{array}$ & FOI Value \\
\hline 1 & Albizia occidentalis Brandegee var. occidentalis & 128 \\
\hline 2 & Attalea guacuyule (Liebm. ex Mart.) Zona & 128 \\
\hline 3 & Cedrela odorata $\mathrm{L}$. & 64 \\
\hline 4 & Sideroxylon capiri (A.DC.) Pittier & 64 \\
\hline 5 & Swietenia humilis Zucc. & 64 \\
\hline 6 & Sideroxylon persimile subsp. subsessiliflorum (Hemsl.) T.D. Penn. & 64 \\
\hline 7 & Acanthocereus occidentalis Britton \& Rose & 8 \\
\hline 8 & Pilosocereus purpusii (Britton \& Rose) Byles \& G.D.Rowley & 8 \\
\hline 9 & Stenocereus alamosensis (J.M.Coult.) A.C.Gibson \& K.E.Horak & 8 \\
\hline 10 & Diospyros sphaerantha Standl. & 8 \\
\hline 11 & Enriquebeltrania disjuncta De-Nova \& V. Sosa & 8 \\
\hline 12 & Jatropha sympetala S.F. Blake \& Standl. & 8 \\
\hline 13 & Diodella crassifolia (Benth.) Borhidi & 8 \\
\hline 14 & Bourreria superba I.M.Johnst. var. superba & 7 \\
\hline 15 & Lonchocarpus mutans M. Sousa & 6 \\
\hline 16 & Annona glabra $\mathrm{L}$. & 6 \\
\hline 17 & Aphananthe monoica (Hemsl.) J.-F.Leroy & 6 \\
\hline 18 & Calliandra tergemina (L.) Benth. & 6 \\
\hline 19 & Eugenia acapulcensis Steud. & 6 \\
\hline 20 & Nymphaea elegans Hook. & 6 \\
\hline 21 & Agonandra racemosa (DC.) Standl. & 6 \\
\hline 22 & Ziziphus amole (Sessé \& Moc.) M.C. Johnst. & 6 \\
\hline 23 & Citharexylum affine D. Don & 6 \\
\hline 24 & Bursera simaruba (L.) Sarg. & 5 \\
\hline 25 & Bursera palmeri S.Watson & 5 \\
\hline 26 & Couepia polyandra (Kunth) Rose & 5 \\
\hline 27 & Rourea glabra Kunth & 5 \\
\hline 28 & Ipomoea arborescens (Humb. \& Bonpl. ex Willd.) G.Don & 5 \\
\hline 29 & Diospyros salicifolia Humb. \& Bonpl. ex Willd. & 5 \\
\hline 30 & Erythroxylum havanense Jacq. & 5 \\
\hline 31 & Hura polyandra Baill. & 5 \\
\hline 32 & Jatropha curcas $\mathrm{L}$. & 5 \\
\hline 33 & Coulteria platyloba (S.Watson) N.Zamora & 5 \\
\hline 34 & Enterolobium cyclocarpum (Jacq.) Griseb. & 5 \\
\hline 35 & Haematoxylum brasiletto H.Karst. & 5 \\
\hline 36 & Indigofera suffruticosa Mill. & 5 \\
\hline 37 & Lonchocarpus sericeus subsp. palmeri (Rose)M. Sousa & 5 \\
\hline 38 & Senna fruticosa (Mill.) H.S.Irwin \& Barneby & 5 \\
\hline 39 & Ceiba pentandra (L.) Gaertn. & 5 \\
\hline 40 & Ceiba aesculifolia (Kunth) Britten \& Baker f. & 5 \\
\hline 41 & Ficus cotinifolia Kunth & 5 \\
\hline 42 & Ficus obtusifolia Kunth & 5 \\
\hline 43 & Ficus padifolia Kunth & 5 \\
\hline 44 & Ficus petiolaris Kunth subsp. Petiolaris & 5 \\
\hline 45 & Ficus crocata (Miq.) Miq. & 5 \\
\hline 46 & Exostema mexicanum A.Gray & 5 \\
\hline 47 & Hintonia latiflora (DC). Bullock & 5 \\
\hline 48 & Zanthoxylum caribaeum Lam. & 5 \\
\hline 49 & Zanthoxylum fagara (L.) Sarg. & 5 \\
\hline 50 & Cupania dentata DC. & 5 \\
\hline 51 & Thouinidium decandrum (Bonpl.) Radlk. & 5 \\
\hline
\end{tabular}


Table 4. Set of 74 species identified as priority for conservation.

\begin{tabular}{|c|c|}
\hline Family & Species \\
\hline Acanthaceae & Avicennia germinans (L.) L. \\
\hline Annonaceae & Annona glabra $\mathrm{L}$. \\
\hline Arecaceae & Attalea guacuyule (Liebm. ex Mart.) Zona \\
\hline \multirow[t]{3}{*}{ Bignoniaceae } & Crescentia alata Kunth \\
\hline & Handroanthus chrysanthus (Jacq.) S.O.Grose \\
\hline & Handroanthus impetiginosus (Mart. ex DC.) Mattos \\
\hline Bixaceae & Cochlospermum vitifolium (Willd.) Spreng \\
\hline Boraginaceae & Bourreria superba I.M.Johnst. var. superba \\
\hline \multirow[t]{2}{*}{ Burseraceae } & Bursera palmeri S.Watson \\
\hline & Bursera simaruba $(\mathrm{L})$. Sarg. \\
\hline \multirow[t]{3}{*}{ Cactaceae } & Acanthocereus occidentalis Britton \& Rose \\
\hline & Pilosocereus purpusii (Britton \& Rose) Byles \& Rose \\
\hline & Stenocereus alamosensis (J.M.Coult.) A.C.Gibson \& K.E.Horak \\
\hline Cannabaceae & Aphananthe monoica (Hemsl.) J.-F.Leroy \\
\hline Capparaceae & Crateva tapia $\mathrm{L}$. \\
\hline Chrysobalanaceae & Couepia polyandra (Kunth) Rose \\
\hline \multirow[t]{2}{*}{ Combretaceae } & Conocarpus erectus $\mathrm{L}$. \\
\hline & Laguncularia racemosa (L.) C.F. Gaertn. \\
\hline Connaraceae & Rourea glabra Kunth \\
\hline Convolvulaceae & Ipomoea arborescens (Humb. \& Bonpl. ex Willd.) G.Don \\
\hline \multirow[t]{2}{*}{ Ebenaceae } & Diospyros salicifolia Humb. \& Bonpl. ex Willd. \\
\hline & Diospyros sphaerantha Standl. \\
\hline Erythroxylaceae & Erythroxylum havanense Jacq. \\
\hline \multirow[t]{4}{*}{ Euphorbiaceae } & Enriquebeltrania disjuncta De-Nova \& V. Sosa \\
\hline & Hura polyandra Baill. \\
\hline & Jatropha curcas L. \\
\hline & Jatropha sympetala S.F. Blake \& Standl. \\
\hline \multirow[t]{15}{*}{ Fabaceae } & Albizia occidentalis Brandegee var. occidentalis \\
\hline & Albizia tomentosa (Micheli) Standl. \\
\hline & Calliandra tergemina (L.) Benth. \\
\hline & Coulteria platyloba (S.Watson) N.Zamora \\
\hline & Enterolobium cyclocarpum (Jacq.) Griseb. \\
\hline & Gliricidia sepium (Jacq.) Kunth ex Walp. \\
\hline & Guilandina bonduc L. \\
\hline & Haematoxylum brasiletto H. Karst. \\
\hline & Indigofera suffruticosa Mill. \\
\hline & Leucaena leucocephala (Lam.) de Wit \\
\hline & Lonchocarpus mutans M. Sousa \\
\hline & Lonchocarpus sericeus subsp. palmeri (Rose) M. Sousa \\
\hline & Pithecellobium dulce (Roxb.) Benth. \\
\hline & Prosopis juliflora (Sw.) DC. \\
\hline & Senna fruticosa (Mill.) H.S.Irwin \& Barneby \\
\hline Lamiaceae & Vitex mollis Kunth \\
\hline \multirow[t]{4}{*}{ Malvaceae } & Ceiba aesculifolia (Kunth) Britten \& Baker f. \\
\hline & Ceiba pentandra (L.) Gaertn. \\
\hline & Guazuma ulmifolia Lam. \\
\hline & Luehea candida (DC.) Mart. \\
\hline Marantaceae & Thalia geniculata $\mathrm{L}$. \\
\hline \multirow[t]{2}{*}{ Meliaceae } & Cedrela odorata $\mathrm{L}$. \\
\hline & Swietenia humilis Zucc. \\
\hline \multirow[t]{5}{*}{ Moraceae } & Ficus cotinifolia Kunth \\
\hline & Ficus crocata (Miq.) Miq. \\
\hline & Ficus obtusifolia Kunth \\
\hline & Ficus padifolia Kunth \\
\hline & Ficus petiolaris Kunth subsp. Petiolaris \\
\hline Myrtaceae & Eugenia acapulcensis Steud. \\
\hline Nymphaeaceae & Nymphaea elegans Hook. \\
\hline Opiliaceae & Agonandra racemosa (DC.) Standl. \\
\hline Polygonaceae & Coccoloba barbadensis Jacq. \\
\hline Rhamnaceae & Ziziphus amole (Sessé \& Moc.) M.C. Johnst. \\
\hline
\end{tabular}




\begin{tabular}{|c|c|}
\hline Family & Species \\
\hline Rhizophoraceae & Rhizophora mangle $\mathrm{L}$. \\
\hline \multirow[t]{3}{*}{ Rubiaceae } & Diodella crassifolia (Benth.) Borhidi \\
\hline & Exostema mexicanum A.Gray \\
\hline & Hintonia latiflora (DC.) Bullock \\
\hline \multirow[t]{2}{*}{ Rutaceae } & Zanthoxylum caribaeum Lam. \\
\hline & Zanthoxylum fagara (L.) Sarg. \\
\hline \multirow[t]{2}{*}{ Salicaceae } & Casearia nitida Jacq. \\
\hline & Salix nigra Marshall \\
\hline \multirow[t]{3}{*}{ Sapindaceae } & Cupania dentata DC. \\
\hline & Sapindus saponaria $\mathrm{L}$. \\
\hline & Thouinidium decandrum (Bonpl.) Radlk. \\
\hline \multirow[t]{2}{*}{ Sapotaceae } & Sideroxylon capiri (A.DC.) Pittier \\
\hline & Sideroxylon persimile subsp. subsessiliflorum (Hemsl.) T.D. Penn. \\
\hline Verbenaceae & Citharexylum affine D. Don \\
\hline
\end{tabular}
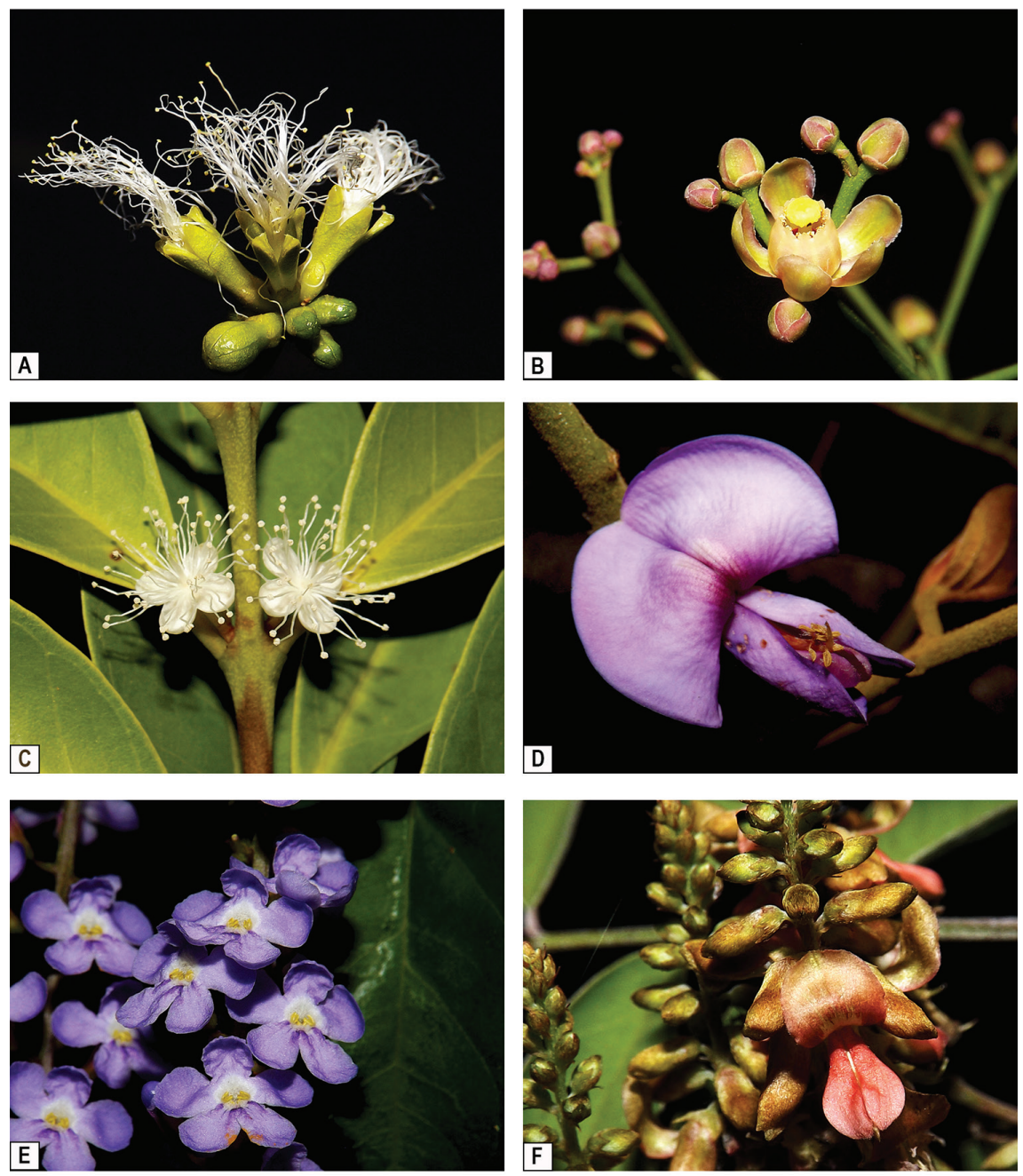

Figure 4. Examples of several priority species in the flora of south Sinaloa, Mexico. A Albizia occidentalis Brandegee var. occidentalis, B Swietenia humilis Zucc., C Eugenia acapulcensis Steud., D Lonchocarpus sericeus subsp. palmeri (Rose) M. Sousa, E Citharexylum affine D. Don, F Indigofera suffruticosa Mill. 


\section{Discussion}

The floristic inventory shows that the Region of Palmito de Verde follows a pattern similar to others sites in Mexico, in relation to the more abundant families. The family Fabaceae usually is the most common in dry and semideciduous forest in the country (Lott et al. 1987; Gentry 1995; Zamora-Crescencio et al. 2008; Rocha-Loredo et al. 2010; Gutiérrez-Báez et al. 2011; Gutiérrez-Báez et al. 2012; León-de la Luz et al. 2012; Dzib-Castillo et al. 2014; Méndez-Toribio et al. 2014; Bravo-Bolaños et al. 2016; Gutiérrez-Báez et al. 2016; Gutiérrez-Báez et al. 2017; Zamora-Crescencio et al. 2017). In relation to Mangroves, this information only reinforces what has already been published by Blanco y-Correa Magallanes (2011). The set of information obtained in this study contributes to the completion of the botanic data of Sinaloa National Marshes and surrounding areas.

A database about the species richness in the region is very scarce, e.g. CONANP (2008) recorded 35 species, by the RPV; CONANP (2013) recorded 51 species and Valdez-Hernández (2002) recorded 82 species for the Nayarit National Marshes, an adjacent region. Thus, the outcomes of this investigation seek to encourage the researches focused on the knowledge and conservation of flora in the Region Priority for Conservation National Marshes.

The method developed during the project to determine species floristic originality enabled the determination of a set of 51 species of concern for conservation over which multiplication capacity (sexual or vegetative) could be focused on for forest restoration aims. An additional set of 23 species meeting the most characteristics as "framework" species may be considered since they can withstand harsh conditions in areas of open vegetation (Betts 2013) in the RPV.

Some "framework" species, such as Leucaena leucocephala (Lam.) de Wit (Fabaceae), Prosopis juliflora (Sw.) D.C. (Fabaceae), Vitex mollis Kunth (Lamiaceae), Guazuma ulmifolia Lam. (Malvaceae), Thalia geniculata L. (Marantaceae), Casearia nitida Jacq. (Salicaceae) Pithecellobium dulce (Roxb.) Benth. (Fabaceae), Luehea candida (DC.) Mart. (Malvaceae) and Salix nigra Marshall (Salicaceae), among others, can be considered as common species. Nevertheless, their use for restoration may accelerate natural regeneration in restoring a multi-layer forest canopy and favor the recovery of nutrient cycles on disturbed sites (Blakesley et al. 2002; Elliott et al. 2003).

While some recommend no more than $10 \%$ of the species for conservation topic (Elliott et al. 2013), we consider that the currently available information allows us to lead conservation, reproduction and restoration programs with this number of selected priority species (Table 4) representing 30\% of the area's identified flora.

However, to be applied, this methodology must first address three issues and limitations. This scheme contributes to the prioritization of species from a conservation biology point of view. It is therefore useful in programs aimed at rehabilitating the structure and functioning of plant associations in a given region (Mudappa and Raman 2010; Peel 2010; Goosem and Tucker 2012; Neidel et al. 2012; Elliott 
et al. 2013). The features of a species determined by this method may be subject to change through time and therefore it should be updated on a regular basis. The characteristics found by this method are directly influenced by the ecological niche of the different species to be evaluated, so it must be considered that the generated information is local. It hence cannot be extrapolated to a larger scale because environmental gradients affect the patterns of flowering, the number of viable seeds, germination, abundance and other factors (Godsoe 2010; Chase 2011; Cox et al. 2016).

\section{Conclusion}

In the current study, the modified Floristic Originality Index model developed during this project has identified a set of most vulnerable and rare species to select "priority" and "framework" tree species able to restore forests structure and biodiversity as well as ecosystem functions. Fifty-one conservation "priority" and 23 "framework" species were selected herein, completing available data for production and reforestation works in the Region of Palmito de Verde. Some guidelines to obtain seeds, seedlings and cuttings for wildlife management and restoration were also proposed.

\section{Acknowledgments}

The first author wishes to express his gratitude to the Master's degree program team at the Autonomous University of Sinaloa's Faculty of Sea Sciences, as well as to the team of UNAM-FONATUR's Program of Integral Management of Vegetation. He also wants to thank cordially Dr. David Ernesto Serrano-Hernández for his valuable comments, to Ph.D. Heather Regan for his contribution in writing to English, to M. Sc. Márcio Verdi for his support in the translation to Portuguese, as well as to the other reviewers for their contribution.

This study was supported by the Consejo Nacional de Ciencia y Tecnología CONACyT (769304), by the Programa de Fomento y Apoyo a Proyectos de Investigación (PROFAPI2015/039) of the Autonomous University of Sinaloa, by Azteca Lighting and by the Tultepec municipality, State of Mexico.

\section{References}

Addo-Fordjour P, Obeng S, Anning AK, Addo MG (2009) Floristic composition, structure and natural regeneration in a moist semi-deciduous forest following anthropogenic disturbances and plant invasion. International Journal of Biodeversity and Conservation 1(2): 21-37.

Aguilar-Sierra C, Martínez E, Arriaga-Cabrera L (2000) Deforestación y fragmentación de ecosistemas: ¿Qué tan grave es el problema en México? Biodiversitas (Surakarta) 30:7-11. Amador-Cruz F, Benítez-Pardo D, Briseño-Dueñas R (2017) Primer registro de Vigna vexillata (Leguminosae, Papilionoideae) en el Estado de Sinaloa. Acta Botánica Mexicana 121: 169-176. https://doi.org/10.21829/abm121.2017.1243 
Assefa D, Rewald B, Sandén H, Rosinger C, Abiyu A, Yitaferu B, Godbold DL (2017) Deforestation and land use strongly effect soil organic carbon and nitrogen stock in Northwest Ethiopia. Catena 153: 89-99. https://doi.org/10.1016/j.catena.2017.02.003

Benítez-Pardo D, Amador-Cruz F, Briseño-Dueñas R (2016) Informe final del programa de Manejo Integral de Vegetación (Technical report). In: UNAM-FONATUR (Eds) Seguimiento al cumplimiento de los programas ambientales del proyecto "Centro Integralmente Planeado Costa Pacífico (ahora Playa Espíritu), en el municipio de Escuinapa, Sinaloa” para el ciclo 2016. Universidad Nacional Autónoma de México, Mazatlán, 1-56. Benítez-Pardo D, Villanueva-Hinojosa S, Briseño-Dueñas R (2017) Informe final del programa de Manejo Integral de Vegetación (Technical report). In: UNAM-FONATUR (Eds) Seguimiento al cumplimiento de los programas ambientales del proyecto "Centro Integralmente Planeado Costa Pacífico (ahora Playa Espíritu), en el municipio de Escuinapa, Sinaloa" para el ciclo 2017 Universidad Nacional Autónoma de México, Mazatlán, 1-48. Benítez-Pardo D, Partida-Ramos DE, Amador-Cruz F, Briseño-Dueñas R (2018) Informe final del programa de Manejo Integral de Vegetación (Technical report). In: UNAM-FONATUR (Eds) Seguimiento al cumplimiento de los programas ambientales del proyecto "Centro Integralmente Planeado Costa Pacífico (ahora Playa Espíritu), en el municipio de Escuinapa, Sinaloa” para el ciclo 2018. Universidad Nacional Autónoma de México, Mazatlán, 1-50.

Betts $H$ (2013) The framework species approach to forest restoration: using functional traits as predictors of species performance. Thesis of $\mathrm{PhD}$, University of Liverpool, Liverpool, $218 \mathrm{pp}$. Blakesley D, Hardwick K, Elliot S (2002) Research needs for restoring tropical forests in Southeast Asia for wildlife conservation: Framework species selection and seed propagation. New Forests 24(3): 165-174. https://doi.org/10.1023/A:1021311700220

Blanco y-Correa Magallanes JM (2011) Diagnóstico funcional de Marismas Nacionales. Universidad Autónoma de Nayarit-Comisión Nacional Forestal, Guadalajara, 189 pp.

Bravo-Bolaños O, Sánchez-González A, De Nova-Vázquez JA, Pavón-Hernández NP (2016) Composición y estructura arbórea y arbustiva de la vegetación de la zona costera de Bahía de Banderas, Nayarit, México. Botanical Sciences 94(3): 603-623. https://doi. org/10.17129/botsci.461

Brédif H, Simon L (2014) Ordinary Biodiversity, Local Stakeholders and Forest Management as a Driver for Regional Sustainable Development. Open Journal of Forestry 4(3): 249-258. https://doi.org/10.4236/ojf.2014.43032

Broennimann O, Vittoz P, Moser D, Guisan A (2005) Rarity types among plant species with high conservation priority in Switzerland. Botanica Helvetica 115(2): 95-108. https:// doi.org/10.1007/s00035-005-0713-z

Chase JM (2011) Ecological niche theory. In: Scheiner SM, Willig MR (Eds) The theory of ecology. University of Chicago Press, Chicago, 93-108.

Chazdon RL (2014) Second growth: the promise of tropical forest regeneration in an age of deforestation. Chicago, University of Chicago Press, 449 pp. https://doi.org/10.7208/ chicago/9780226118109.001.0001

CITES (2017) The Convention on International Trade in Endangered Species of Wild Fauna and Flora. https://cites.org/ 
CONAFOR (2014) Inventario Estatal Forestal y de Suelo-Sinaloa 2013-2014. Comisión Nacional Forestal-Secretaría de Medio Ambiente y Recursos Naturales, Ciudad de México, $164 \mathrm{pp}$.

CONANP (2008) Estudio previo justificativo para el establecimiento del Área Natural Protegida "Reserva de la Biósfera Marismas Nacionales Sinaloa". Comisión Nacional de Áreas Naturales Protegidas, Ciudad de México, 61 pp.

CONANP (2013) Programa de manejo: Reserva de la Biosfera Marismas Nacionales Nayarit. Comisión Nacional de Áreas Naturales Protegidas-Secretaría de Medio Ambiente y Recursos Naturales, Ciudad de México, 200 pp.

Corlett RT (1994) What is secondary forest? Journal of Tropical Ecology 10(3): 445-447. https://doi.org/10.1017/S0266467400008129

Couvet D, Ducarme F (2014) Reconciliation ecology, from biological to social challenges. Revue d'ethnoécologie 6: 1-16. https://doi.org/10.4000/ethnoecologie.1979

Couvet D, Vandevelde JC (2014) Biodiversité ordinaire: des enjeux écologiques au consensus social. In: Casetta E, de Julien D (Eds) La biodiversité en question. Editions Matériologiques, Paris, 181-208. https://doi.org/10.3917/edmat.delor.2014.01.0181

Cox CB, Moore PD, Ladle RJ (2016) Biogeography: An ecological and evolutionary approach. John Wiley \& Sons, Oxford, 512 pp.

Devineau JL, Fournier A, Nignan S (2009) "Ordinary biodiversity" in western Burkina Faso (West Africa): What vegetation do the state forests conserve? Biodiversity and Conservation 18(8): 2075-2099. https://doi.org/10.1007/s10531-008-9574-2

Dzib-Castillo B, Chanatásig-Vaca C, González-Valdivia NA (2014) Estructura y composición en dos comunidades arbóreas de la selva baja caducifolia y mediana subcaducifolia en Campeche, México. Revista Mexicana de Biodiversidad 85(1): 167-178. https://doi.org/10.7550/rmb.38706

Egbinola CN (2015) Impacts of human activities on tree species composition along the forest savanna boundary in Nigeria. The Indonesian Journal of Geography 47(2): 115-123. https://doi.org/10.22146/ijg.9248

Elliott SD, Navakitbumrung P, Kuarak C, Zangkum S, Anusarnsunthorn V, Blakesley D (2003) Selecting framework tree species for restoring seasonally dry tropical forests in northern Thailand based on field performance. Forest Ecology and Management 184(13): 177-191. https://doi.org/10.1016/S0378-1127(03)00211-1

Elliott SD, Blakesley D, Hardwick H (2013). Restauración de Bosques Tropicales: un manual práctico. Royal Botanic Gardens, Kew, Surrey, 344 pp.

Forest Restoration Research Unit (2000) Tree seeds and seedling for restoring forests in Northern Thailand. Chiang Mai University, Thailand, $151 \mathrm{pp}$.

García E (2004) Modificaciones al sistema de clasificación climática de Köppen. Instituto de Geografía-Universidad Nacional Autónoma de México, Ciudad de México, 91 pp.

García EG, Di Stefano JF (2005) Fenología de árbol Sideroxylon capiri (Sapotaceae) en el bosque seco tropical de Costa Rica. Revista de Biología Tropical 53(1-2): 5-14.

Gaston KL, Fuller RA (2007) Commonness, population depletion and conservation biology. Trends in Ecology \& Evolution 23(1): 14-19. https://doi.org/10.1016/j.tree.2007.11.001 
Geist HJ, Lambin EF (2002) Proximate causes and underlying driving forces of tropical deforestation. Bioscience 52(2): 143-150. https://doi.org/10.1641/0006-3568(2002)052[0143:PC AUDF]2.0.CO;2

Gentry AH (1995) Diversity and floristic composition of Neotropical dry forests. In: Bullock SH, Mooney HA, Medina E (Eds) Seasonally dry tropical forests. Cambridge University Press, Cambridge, 146-194. https://doi.org/10.1017/CBO9780511753398.007

Godet L (2010) La “nature ordinaire dans" le monde occidental. L'Espace Geographique 10(4): 295-308. https://doi.org/10.3917/eg.394.0295

Godsoe W (2010) I can't define the niche but I know it when I see it: A formal link between statistical theory and the ecological niche. Oikos 119(1): 53-60. https://doi.org/10.1111/ j.1600-0706.2009.17630.x

Gonçalves FMP, Goyder DJ (2016) A brief botanical survey into Kumbira forest, an isolated patch of Guineo-Congolian biome. PhytoKeys 65: 1-14. https://doi.org/10.3897/phytokeys.65.8679

Goosem S, Tucker NIJ (2012) Repairing the Rainforest. Wet Tropics Management Authority and Biotropica Australia, Cairns, 158 pp.

Gutiérrez-Báez C, Ortiz-Díaz JJ, Flores-Guido JS, Zamora-Crescencio P, Domínguez-Carrasco MR, Villegas P (2011) Estructura y composición florística de la selva mediana subcaducifolia de Nohalal-Sudzal Chico, Tekax, Yucatán, México. Foresta Veracruzana 13(1): 7-14.

Gutiérrez-Báez C, Zamora-Crescencio P, Hernández-Mundo SC (2012) Structure and floristic composition of deciduous forest of Mucuychacan, Campeche, Mexico. Foresta Veracruzana 14(1): 9-16.

Gutiérrez-Báez C, Zamora-Crescencio P, Cabrera-Mis GG (2016) Estructura y composición florística de la selva mediana subperennifolia el remate, Calkiní, Campeche, México. Foresta Veracruzana 18(2): 1-12.

Gutiérrez-Báez C, Folan WJ, Folan L, Silverio G, Zamora-Crescencio P (2017) Estructura y composición florística de la selva mediana subcaducifolia de Imí, Campeche, México. Foresta Veracruzana 19(1): 1-18.

INEGI (1995) 'Límite Nacional 1:4000000’ en División Política Estatal, I.1.2, Atlas Nacional de México. Vol. I. Escala 1:4000000. http://www.conabio.gob.mx/informacion/metadata/gis/conto4mgw.xm l?_xsl=/db/metadata/xsl/fgdc_html.xsl\&_indent=no

INEGI (2013) Uso de suelo y vegetación, escala 1:250000, serie V, escala 1:250000. http:// www.conabio.gob.mx/informacion/metadata/gis/usv250s5ugw.xml?_httpcache=yes\&_ $\mathrm{xsl}=/ \mathrm{db} / \mathrm{meta} \mathrm{data} / \mathrm{xsl} / \mathrm{fgdc} \_$html.xsl\&_indent=no

INEGI (2014) Conjunto de datos vectoriales edafológico, escala 1:250000 Serie II., escala: 1:250000. http://www.conabio.gob.mx/informacion/metadata/gis/eda250s2gw.xm 1? httpcache=yes\&_xsl=/db/metadata/xsl/fgdc_html.xsl\&_indent $=$ no

INEGI (2016) 'División política estatal 1:250000. 2015', escala: 1:250 000. http:// www.conabio.gob.mx/informacion/metadata/gis/dest_2012gw.xml?_httpca che $\%$ E2\%80\%99=\%E2\%80\%99yes\&_xsl=/db/metadata/xsl/fgdc_html.xsl\&_ indent $\% \mathrm{E} 2 \% 80 \% 99=\% \mathrm{E} 2 \% 80 \% 99$ no 
IUCN (2001) IUCN Red List Categories and Criteria: Versión 3.1. International Union for Conservation of Nature, Gland, Switzerland and Cambridge, $31 \mathrm{pp}$.

IUCN (2016) The red list. International Union for Conservation of Nature. http://www.iucnredlist.org/

Kerby J, Elliot S, Maxwell JF, Blakesley D, Anusarnsunthorn V (2000) Tree seeds and seedlings for restoring forests in northern Thailand. Forest Restoration Research Unit, Chiang Mai, $151 \mathrm{pp}$.

Kew RBG (2008) Seed Information Database (SID). Version 7.1 http://data.kew.org/sid/

Kruckeberg AR, Rabinowitz D (1985) Biological aspects of endemism in higher plants. Annual Review of Ecology and Systematics 16(1): 447-479. https://doi.org/10.1146/annurev.es.16.110185.002311

Kweka EJ, Kimaro EE, Munga S (2016) Effect of deforestation and land use changes on mosquito productivity and development in western kenya highlands: Implication for malaria risk. Frontiers in Public Health 4: 238. https://doi.org/10.3389/fpubh.2016.00238

León-de la Luz JL, Domínguez-Cadena R, Medel-Narváez A (2012) Florística de la selva baja caducifolia de la Península de Baja California, México. Botanical Sciences 90(2): 143-162. https://doi.org/10.17129/botsci.480

Lott EJ, Bullock SH, Solís-Magallanes A (1987) Floristic diversity and structure of upland and arroyo forests of coastal Jalisco. Biotropica 19(3): 228-235. https://doi. org/10.2307/2388340

Luize B, Silva T, Venticinque E, Novo E (2015) A floristic survey of angiosperm species occurring at three landscapes of the Central Amazon várzea, Brazil. Check List 11(6): 1789. https://doi.org/10.15560/11.6.1789

Méndez-Toribio M, Martínez-Cruz J, Cortés-Flores J, Rendón-Sandoval FJ, Ibarra-Manríquez G (2014) Composición, estructura y diversidad de la comunidad arbórea del bosque tropical caducifolio en Tziritzícuaro, Depresión del Balsas, Michoacán, México. Revista Mexicana de Biodiversidad 85(4): 1117-1128. https://doi.org/10.7550/rmb.43457

Monjardín-Armenta SA, Pacheco-Angulo CE, Plata-Rocha P, Corrales-Barraza G (2017) La deforestación y sus factores causales en el estado de Sinaloa, México. Madera y Bosques 23(1): 7-22. https://doi.org/10.21829/myb.2017.2311482

Mudappa D, Raman TRS (2010) Rainforest Restoration: A Guide to Principles and Practice. Nature Conservation Foundation, Mysore, $43 \mathrm{pp}$.

Mwakalukwa EE, Meilby H, Treue T (2014) Floristic composition, structure, and species associations of dry Miombo woodland in Tanzania. International Scholarly Research Notices Biodiversity 2014: 1-15. https://doi.org/10.1155/2014/153278

Neidel JD, Consunji H, Labozetta J, Calle A, Mateo-Vega J (2012) Mainstreaming Native Species-Based Forest Restoration: ELTI Conference Proceedings. Smithsonian Tropical Research Institute, Panama City, 89 pp.

NOM-059-SEMARNAT-2010 (2010) Protección ambiental-Especies nativas de México de flora y fauna silvestres-Categorías de riesgo y especificaciones para su inclusión, exclusión o cambio-Lista de especies en riesgo. http://dof.gob.mx/nota_detalle.php?codig $o=5173091 \& f e c h a=30 / 12 / 2010$ 
Peel B (2010) Rainforest Restoration Manual for South-Eastern Australia. CSIRO Publishing, Collingwood, 336 pp. https://doi.org/10.1071/9780643101319

Phillips O, Vásquez Martínez R, Nuñez-Vargas P, Lorenzo-Monteagudo A, Chuspe-Zans ME, Galiano-Sánchez W, Peña-Cruz A, Timaná M, Yli-Halla M, Rose S (2003) Efficient plot-based floristic assessment of tropical forests. Journal of Tropical Ecology 19(6): 629-645. https://doi.org/10.1017/S0266467403006035

R Core Team (2017) R: a language and environment for statistical computing https://www.Rproject.org/

Rabinowitz D (1981) Seven forms of rarity. In: Synge H (Ed.) The biological aspects of rare plant conservation. Wiley, Chichester, 205-217.

Rabinowitz D, Cairns S, Dillo T (1986) Seven forms of rarity and their frequency in the flora of the British Isles. In: Soulé MJ (Ed.) Conservation Biology: the science of scarcity and diversity. Sinauer Associates, Massachussetts, 182-204.

Rocha-Loredo AG, Ramírez-Marcial N, González-Espinosa M (2010) Tree species richness and diversity of the seasonally dry forest in Central Depression of Chiapas. Botanical Sciences 87(1): 89-103. https://doi.org/10.17129/botsci.317

Runyan C, D’Odorico P (2016) Global Deforestation. Cambridge University Press, Cambridge, 265 pp. https://doi.org/10.1017/CBO9781316471548

Sala OE, Chapin FS, Armesto JJ, Berlow E, Bloomfield J, Dirzo R, Huber-Sanwald E, Huenneke LF, Jackson RB, Kinzig A, Leemans R, Lodge DM, Mooney HA, Oesterheld M, Poff NLR, Sykes MT, Walker BH, Walker M, Wall DH (2000) Global biodiversity scenarios for the year 2100. Science 287(5459): 1770-1774. https://doi.org/10.1126/science.287.5459.1770

Sánchez-Salas J, Muro G, Estrada-Castillón E, Alba-Ávila JA (2013) El MER: Un instrumento para evaluar el riesgo de extinción de especies en México. Revista Chapingo Serie Zonas Áridas 12(1): 30-35. https://doi.org/10.5154/r.rchsza.2012.06.037

SEMARNAT (2010) Norma Oficial Mexicana NOM-059-SEMARNAT-2010, Protección ambiental-Especies nativas de México de flora y fauna silvestres-Categorías de riesgo y especificaciones para su inclusión, exclusión o cambio-Lista de especies en riesgo https:// www.gob.mx/profepa/documentos/norma-oficial-mexicana-nom-059-semarnat-2010

Servicio Meteorológico Nacional (2010) Normales climatológicas. http://smn.cna.gob.mx/

Shaheen H, Qureshi R, Akram A, Gulfraz M, Potter D (2014) A preliminary floristic checklist of Thal desert Punjab, Pakistan. Pakistan Journal of Botany 46(1): 13-18.

Tropicos (2019) Tropicos. Missouri Botanical Garden. www.tropicos.org/

Valdez-Hernández JI (2002) Flora vascular de los manglares de Marismas Nacionales, estado de Nayarit. Colegio de Postgraduados, Instituto de Recursos Naturales, Ciudad de México, $12 \mathrm{pp}$.

Vega-Aviña R, Aguiar-Hernández H, Gutiérrez-García JA, Hernández-Vizcarra JA, VegaLópez IF, Villaseñor-Ríos JL (2000) Endemismo regional presente en la flora del municipio de Culiacán, Sinaloa, México. Acta Botánica Mexicana 53(53): 1-15. https://doi. org/10.21829/abm53.2000.858

Villaseñor-Ríos JL (2016) Checklist of the native vascular plants of Mexico. Revista Mexicana de Biodiversidad 87(3): 559-902. https://doi.org/10.1016/j.rmb.2016.06.017 
Whitmore TC (1998) An introduction to tropical rain forests. Oxford University Press, Oxford, $296 \mathrm{pp}$.

Wright SJ, Muller-Landau HC (2006) The future of tropical forest species. Biotropica 38(3): 287-301. https://doi.org/10.1111/j.1744-7429.2006.00154.x

Zamora-Crescencio P, García-Gil G, Flores-Guido JS, Ortiz JJ (2008) Estructura y composición florística de la selva mediana subcaducifolia en el sur del estado de Yucatán, México. Polibotánica 26(1): 39-66.

Zamora-Crescencio P, Rico-Gray V, Barrientos-Medina RC, Puc-Garrido EC, Villegas P, Domínguez-Carrasco MR, Gutiérrez-Báez C (2017) Estructura y composición florística de la selva mediana subperennifolia en Bethania, Campeche, México. Polibotánica 43: 67-86. https://doi.org/10.18387/polibotanica.43.3

\section{Supplementary material 1}

\section{Tables S1, S2}

Authors: Francisco Amador-Cruz, George Bruno Bordenave, Daniel Benítez-Pardo Data type: species data

Explanation note: Table S1. Priority and framework species for the Region of Palmito de Verde, state of Sinaloa, Mexico, with reproductive characteristics after RBG Kew (2008) and Benítez-Pardo et al. (2016, 2017, 2018). Table S2. Inventory Floristic of the Region of Palmito de Verde, state of Sinaloa, Mexico.

Copyright notice: This dataset is made available under the Open Database License (http://opendatacommons.org/licenses/odbl/1.0/). The Open Database License $(\mathrm{ODbL})$ is a license agreement intended to allow users to freely share, modify, and use this Dataset while maintaining this same freedom for others, provided that the original source and author(s) are credited.

Link: https://doi.org/10.3897/neotropical.14.e49166.suppl1 